\title{
Destabilizing Effects of Fair Value Accounting During US Banking Crisis
}

\author{
Petr Hájek ${ }^{1}$, Mansoor Maitah ${ }^{2} \&$ Jan $\breve{C ̆ a d i l}^{3}$ \\ ${ }^{1}$ Department of Economics and Management, Unicorn College s.r.o., Czech Republic \\ ${ }^{2}$ Faculty of Economics and Management, Czech University of Life Sciences Prague, Czech Republic \\ ${ }^{3}$ Department of Economics and Management, Unicorn College s.r.o., Czech Republic \\ Correspondence: Mansoor Maitah, Department of Economics, Faculty of Economics and Management, Czech \\ University of Life Sciences Prague, Kamycka 129, Prague 6 16921, Czech Rep. E-mail: maitah@pef.czu.cz
}

\author{
Received: January 20, 2015 Accepted: April 23, $2015 \quad$ Online Published: July 30, 2015 \\ doi:10.5539/res.v7n11p222 URL: http://dx.doi.org/10.5539/res.v7n11p222
}

\begin{abstract}
The aim of this paper is to analyze the pros and cons of the financial accounting standards rule, known also as Mark-to-Market Rule. Enacted November 15, 2007, required that all companies to be evaluated on the basis of prices reflecting actual market situation. We have shown this pro-cyclical rule significantly worsened the U.S. Financial Crisis of 2007. The article includes a discussion of reasons why US authorities adopted this rule for already third time in history, whereas the two preceding cases are also discussed. The US government did implement the discussed rule just on the eve of the recession or the financial crisis to relatively ease the rule during the period when the US economy was due for a rebound.

Based on our analysis of the definition and strong pro-cyclical effects of MTM rule we have shown that just in the aftermath of factual easing of this rule the economy and equity markets sharply rebounded (other reasons for the last rebound of March 2009 have been discussed too). Timeline of important dates and developments during the US banking crisis of 2007 has been presented and so we hope such a rule will never be adopted again, especially not ahead or just after the start of a financial crisis in any country as it happened in 2007.
\end{abstract}

Keywords: mark-to-market rule, mark-to-model, fas 157, banking crisis, timeline, fair value accounting

\section{Introduction}

The development of economy largely depends on the stability of financial market structures, thus the stability of financial system must be the most pursued objective of state authorities as otherwise the economy simply won't be able to naturally recover from a financial crisis.

One may raise a logical objection that financial crises can possibly have positive influence on any economy as it can filter all the negative and destructing activities of various people or financial structures. Very vivid examples of this can be the activities of Enron or WorldCom that were acknowledged in 2001 and 2002, just after the well-known Dot-Com Bubble. However, we cannot ignore the price paid for such a clean-up as huge scandals and enormous financial decline can happen also during standard recession phases which afterwards can possibly be called "positive" aspects of a regular business cycle.

On the other hand any financial crisis gives rise to enormous decline in the economy and the first thing that comes to one's mind is why to go through this massive crisis if a standard recession might well perform all the above mentioned functions just as well? In 2007, when the world economy was going through the most significant boom in its globalized history, news regarding the architecture of various securities started to emerge. The initiators of this news were obviously the financial staff on Wall Street creating derivative products, which no one was able to decompile and see the real price thus making them unable to be evaluated.

The issue emerged once more, when more individuals began questioning what was inside those securities or what they were comprised of. This was the case with so many types of securities and derivative products ranging from comparably transparent mortgage backed securities to absolutely opaque credit derivatives, such as synthetic collateralized debt obligations. This was still the period when for instance mortgage backed securities could be valued according to mathematical models as there was a specific nominal value of an obligation and its 
cash flow so if the creditor institution received timely payments from the debtor the value for which this security was traded between market participants did not change significantly in time. The price was dependant on internal suppositions or financial models that rely on a complex set of various variables and timeframes. This created a situation when assumptions needed to be used to determine the cost of this or that security or asset in general.

\subsection{Fair Value Accounting and Historical Evidence}

Starting from 2007 we have experienced that Federal Reserve obtained more and more authority over the financial market supervision and regulation to effect the governing macroeconomic policy. Based on a profound study of the case (Simonson \& Hempel, 1993), it can be argued that interagency 1938 Uniform Agreement on Bank Supervisory Procedures was to establish the same objective. They claim that Fed, in comparison to other banking agencies, sought greater leniency in bank examination in order to motivate credit creation while the main aim was to modify supervisory standards to match domestic macroeconomic policies. Year 1938 is obviously not the only example in history. The same thing occurred in 1991-92 when the authorities attempted to ease the credit crunch by subordinating bank examinations in case the debtor asked for more credit.

That is to say there are two groups of economists confronting against each other and arguing about importance of their own reasons.

\subsection{Votes against the Mark-To-Model}

The camp of economists who support MTM rule or fair value accounting, based on market price, claim that, according to Simonson and Hempel (1993, p. 250), mark-to-model allows for "regulatory evaluation condescension by allowing troubled banks and thrifts to use misguiding accounting methods that industrialize undoubtedly biased values of their assets and capital. Such accounting distortions resolute regulators to escape admitting bank and thrift failures in a timely method, and to delay resolving them". This particular approach is highly important as late resolution often increases the costs in a very dramatic way. Without resolution it makes it possible for bank managers and administration to prevent accounting from depreciation when the assets and capital of a financial company are close to going underwater. The average cost of forbearance between 1980 and 1990 according to (Congressional Budget Office, 1991) was about \$66 billion in 1990 dollars. On the other hand (Gilbert, 1992) finds no links between the period of time poorly capitalized banks are allowed to operate and the size of losses to the Bank Insurance Fund.

The inability to detect and close insolvent or near-bankrupt banks in the presence of a deposit guarantee scheme may embolden portfolio managers to bet on resurrection by taking greater risk in hopes of higher return on investments. If such a scenario does not actually work as planned, then what happens is that the company eventually ends up in the hands of Federal Deposit Insurance Corporation (FDIC). (Note 1)

Another huge problem that this group of economists emphasizes is that subordination of supervision to Federal Reserve inevitably leads to supervisory leniency as the combination of Fed's supervisory and monetary policy aims greatly oppose each other. For instance (The Hunt Commission Report, 1971) criticized the regulatory environment as the Fed's duties for supervision of financial market corporations diverged from responsibilities related to managing monetary policy. In complete compliance with the current report but with a totally different stress a House Banking Committee report on reforming the financial system characterized the potential use of bank authorities to achieve monetary policy objectives as a dangerous application of bank supervision (U.S. Congress, 1974).

Manfred Peterson analyzed the opinions of potential conflicts and compatibility of Fed's supervision and monetary policy objectives and ascertained that in general sense "bank examination data are not useful in formulating open market policy" (Peterson, 1977). However, he gave strong reasoning to the legitimacy of linking the application of specific monetary actions (credit controls, discount window administration), and sectors of credit markets as well as private banks (Peterson, 1977, pp. 34-36). He observed that the conflicts of objectives can from time to time be resolved exclusively by banking agencies and only in rare cases they should be brought to public arena.

We have to keep in mind that it was Great Depression that brought fair value accounting into balance sheet valuations. Various historical examples testify to the fact that when MTM was effective $(1929,1938,1990,2007)$ that is to say during credit crunches, when market valuations were moving down, the balance sheets were damaged from all sides simply because of the depressed market prices without any consideration of debt repayments generating unchanged cash flows.

\subsection{Votes against Mark-To-Market}

However, the other camp of economists claim that fair value accounting causes strong pro-cyclical movements 
of balance sheet valuations which might "artificially" produce huge returns during economic expansion and great losses in the time of decline. We suggest to discuss a simple example: security nominal value is $\$ 100$ while it produces annual cash flow of $\$ 10$. According to historical prices and mathematical models it would be priced more or less steadily under mark-to-model accounting without taking into consideration its market value, despite the fact that it would no doubt be positively biased. However under mark-to-market accounting, when the price of assets would go up by $100 \%$ its value would artificially become double though it is the very same security, as it used to be. The problem was not only in MTM rule, but it was the deadly combination of MTM performance (just ahead of financial recession) and the debtors' loans derivatives, which were ironically, rated AAA.

Long time ago Jacob Viner opted for the subordination of bank supervision to macroeconomic policies. He predicted the negative trend of bank examiners to make judgments on loans in respect to economic perspective, by calling for credit expansion in boom phases and strengthening credit contraction during economic declines or recessions. Considering the fact that he was against such perversity he urged the authorities to adopt centralization of the bank examining functions under the Fed which would help to effectively combine "examination policy with credit control policy" (Viner, 1939, pp. 109-110).

George Bach (1949) was absolutely for this approach. He directly addressed the "optimal relationship" between "bank supervision and monetary (credit) policy" based on the results of Hoover Commission on the Organization of the Executive Branch of the Government

In retrospective on the 1938 Uniform Agreement, he acclaimed the conferees to "avoid examination pressure to liquidate intrinsically sound assets in time of deflation" (Bach, 1949, pp. 280-281).

Next to Viner and Bach also Homer Jones, chief economist of the FDIC in the late 1930s, pointed out that the Uniform Agreement corrected supervisory rules that may have contributed to depression conditions. Not considering monetary policy issues or fiscal policies, he speculated that the new leniency in examination might contribute to economic recovery. Nevertheless, he doubted the usefulness of bank supervision for monetary control (Jones, 1940).

In the mirror of all these comments Simonson and Hempel (1993, p. 251) stressed out that to ignore costs of supervisory leniency was "grave omission, given the apparent contribution of valuation forbearance policies to the collapse of many banks and of the savings and loan industry during the 1980s and early 1990s." (Note 2) The discussion which took place between 1950s and 1970s relatively calmed down and was now less significant due to more or less untroubled economic and banking situation of the given period, when Donald Jacobs urged for greater discretion in bank supervision methods, that could contribute to mitigating business cycles and evading conflicts regarding monetary policy (Jacobs, 1964).

\section{Method}

What was the reason for introducing and then abolishing the mark-to-market rule several times throughout the history? While the rule was in force already during the Great Depression, it was eased in 1938 shortly after its adoption during the recession, the first remarkable economic recession following the Depression. A number of economists claimed that it is required for the banking system to provide more credit to the ones who really need it. In 1937-38 banks were accused of hampering an economic recovery shortly after they emerged from severe economic conditions of the thirties. Soon, once the faith in the economy seemed to be growing, the economy experienced a sudden recession. Banks were accused for hindering economic recovery by restricting lending.

In order to ease examination pressures, the banking regulatory agencies (FDIC, Comptroller of the Currency and the Fed) negotiated and created the 1938 Uniform Agreement on Bank Supervisory Procedures which was revised in 1949 and 1979. Simonson and Hempel (1993, pp. 249-250) present their findings that "researchers who have studied the effects of the 1938 Uniform Agreement generally concluded that the accounting distortions it created tended to disguise bank and thrift insolvencies, invited regulatory laxity and forbearance, and supported noneconomic decision making by bankers." However, they stress out that researchers did not tackle the issue of broader macroeconomic objectives related to the conflict of supervision and monetary policy underlying the Agreement.

Financial institutions experienced in 1991-1992 about the same accusations as in 1938 and again it lead the mark-to-market rule to stay longer in place. The case was paralleled almost identically when the administration and regulatory authorities claimed that the credit crunch could be healed by subordination of bank examination to the greater necessity for more bank credit.

In both of the previously discussed cases the economy managed to restore itself amazingly quickly. In the next part we will present commented chronology from implementation to the abolishment of mark-to-market rule 
during the U.S Banking crisis of 2007 as well as show that the same rapid recovery happened for the third time.

\subsection{Timeline of Mark-To-Market Related Events}

We will commence our historical overview of Mark-to-Market related questions during the financial crisis of 2007 with a few comments about derivatives that Warren Buffet made long time ago in his written request to shareholders in 2002 (Buffet, 2002). "We view them [derivatives] as time bombs, both for the parties that deal in them and the economic system. ...the parties to derivatives also have enormous incentives to cheat in accounting for them. Those who trade derivatives are usually paid (in whole or part) on 'earnings' calculated by mark-to-market accounting. But often there is no real market... and 'mark-to-model' is utilized. This substitution can bring on large-scale mischief [as] ...expert auditors could easily and honestly have widely varying opinions [regarding valuation]." He also mentions examples: "In recent years, some huge-scale frauds and near-frauds have been facilitated by derivatives trades. ... In the energy and electric utility sectors, for example, companies used derivatives and trading activities to report great 'earnings'- until the roof fell in when they actually tried to convert the derivatives-related receivables on their balance sheets into cash. 'Mark-to-market' then turned out to be truly "mark-to-myth." Then he concludes "The derivatives genie is now well out of the bottle, and these instruments will almost certainly multiply in variety and number until some event makes their toxicity clear."

So FASB rule \#157 came into force on Thursday, November 15, 2007. Under the newly adopted rule, the Financial Accounting Standards Board (FASB) defined three groups of assets. Level 1 (mark-to-market) assets are widely traded and have readily available and standard market prices. Level 2 (mark-to-model) securities are not traded actively, but they are comprised of elements that have market prices, e.g., interest-rate swaps. Level 3 (mark-to-myth) assets are based on management estimates as there is either too little or no hard pricing information available. New rules were to be applied to come as close as possible to what the board calls "fair value measurements" for most assets banks and their SIVs have on their balance sheets. The definition of FAS 157 modified the pricing according to the entry price to exit price regardless of the future plans of the entity about this very asset, be it indented to be sold later or kept for investment.

Stephen Taub wrote in his article for CFO.com (Taub, 2007) that "The Royal Bank of Scotland Group estimates that U.S. banks and brokers, already under massive losses caused by the collapse in the subprime credit market, potentially face hundreds of billions of dollars in write-offs because of what are called Level 3 accounting rules, according to Bloomberg." He cites Bob Janujah, back then Royal Bank's chief credit analyst who wrote the very same day: "The U.S. Financial Accounting Standards Board Rule 157, which is effective for [any entities beginning] fiscal years after November 15, 2007, will make it harder for companies to avoid putting market prices on securities considered hardest to value, known as Level 3 assets, the wire service reported. ... The heat is on and it is inevitable that more players will have to revalue at least a decent portion" of assets they currently value using "mark-to-make believe."

According to Stephen Taub, Bob Janjuah mentioned that, for instance, "Morgan Stanley has the equivalent of $251 \%$ of its equity in Level 3 assets, Goldman Sachs has 185 percent, Lehman Brothers has 159 percent and Citigroup has 105 percent, according to Bloomberg data". On the other hand, Merrill Lynch has Level 3 assets equal to 38 percent of its equity. As a result, Janjuah believes Merrill "may well come out of all of this in the best health."

The definition of FAS 157 changed the pricing based on entry price but on exit price (so no matter the price for which you bought a cash flow generating bond, you have to reprice it in respect to current market price), regardless of whether the entity plans to hold the asset for investment or resell it later. Also, FAS 157 emphasizes that fair value is market-based rather than entity-specific.

At the end of November 2007, there were opinions that liquidity issues should be anticipated. For instance (Centralbanking.com, 2007), ECB declared 11/23/2007 "it will inject more liquidity into the Euro zone money market in a bid to allay 'the re-emerging risk of volatility'." Interbank rates started to increase again. The IMF's October Global Financial Stability Report (2007) (IMF, 2007) makes its own estimates on mark-to-market losses of around \$200 billion since February 2007 on all nonprime mortgage-related assets. According to the (OECD's Financial Markets Highlights of November, 2007) about half of the predicted 1.3 trillion USD in CDOs was acquired by hedge funds, a quarter by banks, and the rest by asset managers and insurance agencies. Banks invested more funds in BB to BBB rated securities and equity shares. Approximately three quarters of CDOs, were purchased in the USA, and less than $20 \%$ in Europe. So we can observe that most of the dangerous toxic junk was dumped in the USA, and nowhere else.

Holman W. Jenkins wrote in his WSJ column on March 5, 2008 (Jenkins, 2008) that mark-to-market idea-commenting on FAS 115 "Accounting for Certain Investments in Debt and Equity Securities" enacted in 
May 1993 - "was a gift to the world from SEC Chief Richard Breeden in the early '90s. With the help of accounting mavens, he argued that requiring banks and other companies to account for financial assets at current market prices, as if the institutions were being sized up for liquidation, would provide a rough tough discipline for the edification of investors, regulators and managers." He also draws the attention to the fact that "many questioned Mr. Breeden's initiative at the time, among them Fed Chairman Alan Greenspan and Bank of America's Richard M. Rosenberg. Particularly notable were their warnings that the new rule, when combined with risk-based capital standards, might lead banks to hold fewer loans on their own books, packaging more of them as complex securities for sale to investors." "Overlooked, too, was a phenomenon we perhaps understand better today [during fire-sales]: the propensity of the speculators who provide much of the market's day-to-day liquidity to go on strike during moments when their services are most needed. 'Mark to market' then becomes something else, because markets no longer exist for many of these abstruse securities. Banks are left oxymoronically trying to estimate what market prices would be if markets existed." Thus what we can see is that the discussion regarding cons and pros of Market To Market will probably last forever.

In the 2/26/2008 FT, John Dizard expressed his concerns about the most probable scenario (Dizard, 2008): i.e. that the values of assets in larger banks are declining more rapidly than they are capable to raise new capital. "The problem, I can assure you, is becoming acute. You know, like this quarter acute. The accountants are no longer the pliant figures of yore, ready to take the bankers' or dealers' word that some bond or loan, or CDO squared is worth what they say it is". Furthermore, as one board member of a very large dealer told me: "Aside from the shrinking capital (from mark to market losses), you are getting more and more assets being put in the illiquid 'bucket' [by the accountants]. Those illiquid assets require a bigger capital charge, so you are getting a double whammy." What come to mind first after his sharp notice is why not simply free the market of these rules and value all the assets based on cash flow and as investments held to maturity?

On 2/28/2008, during the discussions after Mr. Bernanke's presentation, Senator Charles Schumer addressed the Fed Chairman with a question regarding the role of fair-value accounting method in reinforcing the huge mess in the credit markets. Mr. Bernanke replied to Schumer, with despair (Bernanke, 2008a): "I think...it's one of the major problems that we have in the current environment. I don't know how to fix it. I don't know what to do about it." When the Senator suggested that the mark-to-market rule should therefore be abolished, Mr. Bernanke proceeded in the same manner, "I agree there's a severe problem. It's difficult to change the rules in the middle of a crisis." It is unbelievable that Fed's team full of professional economists could not develop any methods how accountants could tweak the MTM rule to evade its consequences of plummeting bank asset values?

In the 2/29/2008 FT, Paul J. Davies noticed that in April 1993, in response to the S\&L crisis, FASB adopted a rule [FAS 115] that elbowed the way for the common use of mark-to-market accounting. He observed "fair-value accounting has been pro-cyclical, exacerbated the credit cycle by stimulating lending orgies during booms and credit crunches during busts" (Davies, 2008).

Almost all financials, including AIG or Lehman Brothers, have suggested revise the discussed rule. According to the 3/14/2008 WSJ, the SEC "is expected to tell public companies that while they still need to use market prices for many of the instruments they hold no matter how bad those prices look, they can also give investors a wider range of the possible values for those securities" (WSJ Heard on the Street, 2008).

We have to emphasize the fact that the most severe problem about MTM was that the losses it caused were unrealized losses so they had the potential to turn into profit when the market value of loans and securities held by banks was restored. Mark-to-market losses were even aggravated due to the fact that they were generally based on Market's traded ABX indexes, which are very illiquid and based on very illiquid securities. Once the credit crisis was less severe, most of the mark-to-market losses transformed into huge gains, at least in percentage change terms

According to IMF's April 2008 Global Financial Stability Report (IMF, 2008) the mark-to-market losses on structured derivatives are estimated to make up $\$ 720$ billion. The real losses are now starting to emerge, I mean the ones stemming from bad loans. Banks start to increase their reserves (pile cash, not making loans). On the positive side, banks are still able to raise capital.

Seeing all the mess MTM caused SEC sent a letter in which eased MTM rules a little (SEC, 2008): under distressed market environment a company may shove the asset to Level 3 and price it as they please. To see the extent we should mention that first quarter in 2008 Goldman's Level 3 assets surged 39\% to $\$ 96.4$ billion from $\$ 69.2$ billion. Morgan Stanley's Level 3 assets rose $6.1 \%$ to $\$ 78.2$ billion. Lehman's Level 3 property rose $1.3 \%$ and reached the threshold of $\$ 42.5$ billion (Bloomberg, 2008a).

The profits went on to surpass all expectations through the first quarter of 2008. Financials have reported terrible 
data, but generally due to MTM losses, which were in April 2008 expected to be reversed on a y/y basis by the fourth quarter of 2008. With this on mind, we would like to ask if Lehman had to fail if MTM was suspended in April. 2008.

OECD April report (OECD, 2008) rejected using ABX indices and MTM accounting methods as a way to measure the losses: "Liquidity problems and panic are causing major problems for price discovery, rendering this type of approach invalid." Instead of this, the study uses a default-model to assess the amount of losses making up to $\$ 422$ billion, assuming $40 \%$ recovery on defaulting loans and a house price scenario compared to foregoing outcomes.

"To get anything like recent MTM losses would require a $0 \%$ recovery rate-which seems extreme even for the most bearish." Figure 6 of the report is worth to check because it shows the estimated losses assuming recovery rates of $0 \%, 40 \%, 50$, and $60 \%$. They total $\$ 703 \mathrm{~b}, \$ 422 \mathrm{~b}, \$ 352 \mathrm{~b}$, and $\$ 281 \mathrm{~b}$.

On June 9, 2008, Standard \& Poor's decreased its ratings on more than $\$ 100$ billion in residential mortgage-backed securities backed by bond insurers MBIA and Ambac. This only caused more MTM losses for many companies, holding these securities. That is to say banks found it more and more challenging to raise capital as their bad loans were increasing day by day and as they were forced to cut down their dividends. This foreshadowed that the credit crisis was transforming into a credit crunch. Here we ask once more: "Really nobody saw the negative feedback loop coming?" Since bad MBSs and MTM became the reason for more losses, eventually leading to plumetting stock market, and mixed up with wealth effect it caused more bad MBSs due to existing MTM.

In June 2008 Marc Faber's expressed his own opinion on Level 3 assets, which are classified in "marked-to-myth" category because there are actually no markets for them. They are either priceless or worthless, whichever word you prefer. These assets surpass the capital of the Street's major investment and commercial banks. Marc noted that Level II assets going over $\$ 4$ trillion and rapidly growing are just as worrisome. These are marked-to-model but may be just as illiquid as Level 3 (Faber, 2008). These figures are significant and definitely not nice and obviously been boosted by MTM accounting. It seems to be irrational to mark down the value of performing assets only due to the fact that some illiquid price indices based on illiquid securities have dropped. It is unanimously accepted by the theoreticians of the policy that "fair value" accounting rules have overstated and aggravated the credit crisis and still, none of them takes any measures against this.

The day after Goldman downgraded Citigroup and GM to a lower category, June 27, to sells and eight days after Moody's downgraded the monoline bond insurers, the WSJ published the article "Credit Storm Back With a Vengeance" (WSJ, 2008). Many securities backed by subprime mortgages came close to the down most line and corporate trash bond yields rose on the deteriorating perspective for Chrysler and GM. There were more discussions around this topic like "Hopes fading that worst of the credit crunch is over," in FT, 6/27. "We've had only the first act in credit crisis drama," FT, 6/29. The mood in the credit markets had notably improved in the months following the near-collapse of Bear Stearns in March 2008. Financial companies were able to get rid of some leveraged buy-out debt that remained on their shelves from the boom and could issue and sell new securities. Any big event, like a bankruptcy of another big fund or financial corporation never happened those days so the fears faded in time. Nevertheless, there were tons of bad economic data, fears about further write downs at financial institutions and especially big banks and other problems (like those the car producers were facing) that stressed the investors a lot. The credit crisis worsened and politicians did not lift the MTM rule to help financials so one could only expect failure of a big corporation in the following months. A rather sad article, published in BIS Quarterly Report for Q2 during the first days of September 2008 (Fender \& Scheicher, 2008) drew some important but hardly encouraging conclusions: "A related set of findings concerns the use of ABX price information by market participants and policymakers for the valuation of positions in US subprime instruments. Importantly, the empirical results provide tentative evidence suggesting that observed ABX prices are unlikely to be good predictors of future default-related cash flow shortfalls on outstanding subprime MBS, especially for tranches at the higher end of the capital structure. This is in part because coverage of the ABX indices extends only to a small fraction of the outstanding subprime MBS universe, which can lead to significant price divergence across like-rated products even in the absence of sizeable risk premia."

The Lehman Brothers filed for bankruptcy on September 15, 2008. According to Marketwatch.com (Mamudi, 2008) "The filing remains the largest bankruptcy filing in U.S. history (Note 3), with Lehman's total debts of $\$ 613$ billion against total assets of $\$ 639$ billion." The surge of panic from Lehman's failure swiftly caused international fixed-income markets to shut down and credit spreads to widen significantly. Only 2 days after the shocking event (Bloomberg, 2008b) investors learnt about MTM destructive impact on returns: 'Investors' 
declining appetite for Morgan Stanley debt wound up boosting third-quarter earnings. The firm booked $\$ 1.43$ billion of revenue because a drop in the value of the firm's liabilities allowed it to book an accounting gain."

Under FAS 157, all companies are allowed to allow to MTM their liabilities and report losses as profits, under the theoretical consideration that they could purchase back their debts at a lower price than those they initially paid. In practice, however, troubled businesses won't have the liquidity or motivation to get back their outstanding debt.

Based on the following conference calls (earnings reports) for the 2008Q3 Goldman's Level 3 assets reached the amount of $\$ 68$ billion, or $6 \%$ of its total asset value, in the 2008Q3, Morgan Stanley had \$69 billion in Level 3 during 2008Q2, AIG had \$48.7 bn in Level 3 at the end of Q2 with consolidated shareholders' equity of \$78.1 billion. Lehman had $\$ 41.3$ billion of these toxic securities at last count before the company filed for bankruptcy.

At the SCB hearing on 23 September 2008, Chairman Bernanke suggested to abolish mark-to-market accounting in order to prevent dramatic asset write-downs (Bernanke, 2008b). "Toxic" assets, which had become almost entirely illiquid, could only be sold at "fire sale" prices.

Bernanke argued that these low prices, which had been determined by the market mechanism, may have significantly understated their actual value, and therefore induced excessive write-downs (which in turn required banks to sell more assets or recapitalise in order to meet their capital requirements) (House of Commons, 2009).

On October 13 American Bankers Association sent a written request to SEC imploring him to cancel the M2M as soon as possible (ABA, 2008). ABA chairman and CEO Edward Yingling wrote in his response "Given the importance of this issue, the impact it has on the crisis in the financial markets, and the seeming inability of FASB to address in a meaningful way the problems of using fair value in dysfunctional markets, we believe it is necessary for the SEC to use its statutory authority to step in and override the guidance issued by FASB". "Such action is necessary to meet the SEC's obligation to provide relevant, reliable and useful information to the users of financial statements".

The Federal Home Loan Bank (FHLB) system is a major US debtor, only second to federal government, with [back then] $\$ 1.25$ tn of debt. The banks allow low-cost funds to more than 8,000 member banks and financials. A popular blog Zero Hedge (written by group of economists nicknamed Tyler Durden) drew the attention of masses on the fact that "according to Moody's, as many as 8 of the 12 FHLB regional banks may fall short of minimum capital requirements - which is a scant $4 \%$ of assets! ( $8 \%$ when assets are risk weighted) as auditors require write-downs to market prices (MTM) from their \$76bn of private mortgage-bond holdings" (Durden, 2009). FHL Banks were lobbying their regulatory bodies, and also the SEC and FASB, to abolish MTM at least for them (Bloomberg, 2009). James Lockhart of Federal Housing Finance Agency told Bloomberg: "Conceptually I'm a big believer in fair value, but it's tough in a market like this where there's that fear factor, lack of confidence and lack of liquidity." Applying fair-value accounting method to privately backed mortgage bonds "is somewhat problematic at the moment. It's really hard to get a good market-based fair value because so few of these securities are trading." Do you believe Cox, Paulson, Bernanke, and Geithner couldn't realize this more than a year ago when canceling M2M would have helped to prevent all the disaster and perhaps saved a huge amount of money not only on their payrolls but also in the stock market valuation?

Now in January investors don't believe that the government has done what it takes to fix the credit system. Indeed, whole market speculated there will be a nationalization of many banks. Since February 2008, the S\&P 500 Bank Composite's market cap has tumbled from $\$ 508$ bn to $\$ 111$ bn on Friday 2/20/2009. The government could buy the entire S\&P 500 Financials sector for $\$ 598$ bn at close of 2/23/2009.

Ben Bernanke wrote on 2/25/2009 (Bernanke, 2009): This mechanism is "a good principle in general". He also said that it "shouldn't be suspended entirely". We wonder that it took him so many months to conclude that "Accounting authorities have a great deal of work to do to try to figure out how to deal with some of these assets, which are not traded in liquid markets" he said.

In March 2009. when the stock markets touch their crisis bottoms started to clear up by emergence of good news. Among the good news was the fall in mortgage rates, which followed the Fed's 11/25/2008 announced plan to buy $\$ 600$ bn in Agency debt and securities, which was otherwise called MBS's repurchase program and which was intended to revive banks' refinancing business (start of Quantitative Easing \#1). The monetary and credit rescue projects seemed to be starting to work. The S\&P 500 bottomed on March 6 at an intraday low of 666 . Obama's ARRA (American Recovery and Reinvestment Act) — trillion dollar stimulus package — was already announced and expected. Judging by Citibank's conference calls, its operating earnings shifted to the positive line in 2009Q1. Bank of America and JPMorgan announced similar news. Finally there were talks on the market 
that MTM will be cancelled or materially eased by April 2, day on which FASB plans voting on that issue.

On April 2, 2009 the MTM rule was significantly eased so it became practically suspended. There were some people who believed MTM to be inperceptible, but The Federal Home Loan Banks recorded an overall loss for the 2008Q4 amounting $\$ 672$ million, mainly as a result of write-downs in the cost of "private label" mortgage assets. In April 2009, the stress-tests of the banking sector ended relatively well. The S\&P 500 started its way up in March and April developments only confirmed its strength so it gained $66 \%$ that year.

\section{Discussion}

The overall loss assessment of MTM according to the (IMF, 2009) had risen from $2.2 \mathrm{tn}$. in January to 4 tn. in April. Ironically, the easing of the rule restored the market values of securities, which meant that the Financials could finally report significant gains on them in 2009 which was certainly not the case with 2008 when the MTM rule was deeply affecting the value of securities. There was some tendency in 2009 that MTM would be reinstated again but as Robert McTeer, the ex-president of the Federal Reserve Bank of Dallas, said in January 2011 "Apparently stung from having been pressured by Congress and probably embarrassed over their defeat within the professional accounting community, FASB decided to double down a few months ago. They proposed mark to market accounting, not only for bank holdings of securities, but of loans as well-indeed, the whole balance sheet. That will show them! That overreach made so little sense that it was hard even to discuss it. Well, the good news is that the proposal, which ran counter not only to common sense but counter to the views of the international counterpart of FASB, has apparently collapsed of its own weight. FASB has apparently dropped the proposal and is moving on." (McTeer, 2011). Considering MTM rule, the historical evidence is a good indicator, as it showed us a few times that this rule is almost as distressing and toxic that it can apparently become lethal for many companies and the economy in general. FASB and other policy theoreticians should think twice if they ever want to reiterate it again. The trust in financial stability and financial system is crucial for the economy to operate and this rule proved to be very procyclical bringing very negative effects in reality although the theory behind it can be nice and acceptable. The reality has never been and never will be so.

\section{References}

ABA. (2008, October 13). Banks to SEC: Overrule FASB Fair-Value Guidance. Retrieved from $\mathrm{http}: / / \mathrm{www} . c f o . c o m / a r t i c l e . c f m / 12410482$

Bach, G. L. (1949). Bank Supervision, Monetary Policy, and Governmental Reorganization. Journal of Finance, 269-285.

Barth, J. R., Brumbaugh, D. J., \& Litan, R. E. (1990, December). Banking Industry in Turmoil: A Report on the Condition of the U.S. Banking Industry and the Bank Insurance Fund. Report to the Committee on Banking, Finance and Urban Affairs, House of Representatives, 101st Congress.

Bernanke, B. S. (2008a, February 28). Semiannual Monetary Policy Report to the Congress, Committee on Banking, Housing, and Urban Affairs, U.S. Senate, on February 28, 2008. Retrieved from $\mathrm{http} / / / \mathrm{www}$. federalreserve.gov/newsevents/testimony/bernanke20080227a.htm

Bernanke, B. S. (2008b, September 23). Hearing on US Credit Markets: Recent Actions Regarding Government Sponsored Entities, Investment Banks and Other Financial Institutions, US Senate Committee on Banking, Housing and Urban Affairs. from http://banking.senate.gov/public/index.cfm?Fuseaction=Hearings.Hearing\&Hearing_ID=7a41ae9e-30b2-4d 7f-8f1b-4ef2e8ae28f7

Bernanke, B. S. (2009, February 26). Semiannual Monetary Policy Report to the Congress. Committee on Financial Services, U.S. House of Representatives. Retrieved February 25, 2009, from http://www.federalreserve.gov/newsevents/testimony/bernanke20090224a.htm

Bloomberg. (2008a, April 9). Goldman Sachs Level 3 Assets Jump, Exceeding Rivals' (Update3). Retrieved from http://www.bloomberg.com/apps/news?pid=newsarchive\&sid=aJ8k124ayR7Y

Bloomberg. (2008b, September 17). Morgan Stanley Shares Fall as Profit Fails to Ease Concerns. Retrieved from http://www.bloomberg.com/apps/news?pid=newsarchive\&sid=andTohIJAeN0\&refer=home

Bloomberg. (2009, January 23). Fannie, Freddie, FHLBs Face New Requirements (Update1). Retrieved from http://www.bloomberg.com/apps/news?pid=newsarchive\&sid=aTHQ4Zp11MD4\&refer=home

Buffet, W. (2002). Edited excerpts from the Berkshire Hathaway annual report for 2002. Retrieved August 20, 2009, from http://www.fintools.com/docs/Warren\%20Buffet\%20on\%20Derivatives.pdf 
$\begin{array}{llll}\text { Centralbanking.com. } & \text { (2007, } & \text { November } & \text { 23). }\end{array}$ http://www.centralbanking.com/central-banking/news/1422893/ecb-counter-tensions-extra-funds

Congressional Budget Office. (1991, June). CBO Staff Memorandum: The Cost of Forbearance During the Thrift Crisis. Washington, DC: June.

Davies, P. J. (2008, February 29). True impact of mark-to-market accounting in the credit crisis. Financial Times, 24.

Dizard, J. (2008, February 26). Mark-to-market requirements turn into Doomsday device. Retrieved from http://www.ft.com/intl/cms/s/0/a2631a20-e178-11dc-a302-0000779fd2ac.html\#axzz1VaIBIOFf

Durden, T. (2009, January 26). Fannie, Freddie, FHLB About To Remind World Of Their Pathetic Existence. Retrieved from http://www.zerohedge.com/article/fannie-freddie-fhlb-about-remind-worldtheir-pathetic-existence

Faber, M. (2008, June 1). The Gloom, Boom \& Doom [regular daily] Report.

Fender, I., \& Scheicher, M. (2008, September). The ABX: how do the markets price subprime. Retrieved from http://www.bis.org/publ/qtrpdf/r_qt0809h.pdf

Gilbert, A. R. (1992, July/August). The Effects of Legislating Prompt Corrective Action on the Bank Insurance Fund. Federal Reserve Bank of St. Louis.

House of Commons. (2009, June 23). US Congressional debates on the financial crisis: Key players, policy and future regulation. RESEARCH PAPER, 47.

IMF. (2007, October). Global Financial Stability Report. Retrieved from http://www.imf.org/external/pubs/ft/gfsr/2007/02/index.htm

IMF. (2008, April). Global Financial Stability Report. Retrieved from http://www.imf.org/external/pubs/ft/gfsr/2008/01/index.htm

IMF. (2009, April). Global Financial Stability Report. Retrieved from http://www.imf.org/External/Pubs/FT/GFSR/2009/01/index.htm

Jacobs, D. P. (1964). The Impact of Examination Practices Upon Commercial Bank Lending Policies. Washington D.C.: U.S. Government Printing Office.

Jenkins, H. W. (2008, March 5). Mark to Meltdown? Retrieved October 10, 2009, from http://www.uncle-scam.com/Breaking/march-08/w2sj-3-5.pdf

Jones, H. (1940). An Appraisal of the Rules and Procedures of Bank Supervision, 1929-39 (pp. 183-198).

Mamudi, S. (15. September 2008). Lehman folds with record $\$ 613$ billion debt. Retrieved from $\mathrm{http}: / /$ secure.marketwatch.com/story/lehman-folds-with-record-613-billion-debt

McTeer, R. (1. January 2011). FASB's Return to Mark-to-Market Sanity. Retrieved from http://www.forbes.com/sites/beltway/2011/01/26/fasbs-return-to-mark-to-market-sanity/

Merton, R. C. (1977, June). An Analytic Derivation of the Cost of Deposit Insurance and Loan Guarantees. Journal of Banking and Finance. http://dx.doi.org/10.1016/0378-4266(77)90015-2

OECD. (April 2008). The Subprime Crisis: Size, Deleveraging and Some Policy Options. Retrieved from http://www.oecd.org/dataoecd/36/27/40451721.pdf

OECD's Financial Markets Highlights of November 2007. (November 2007). OECD. Retrieved from http://www.oecd.org/dataoecd/53/18/39654572.pdf

Peterson, M. O. (1977, Autumn). Conflicts Between Monetary Policy and Bank Supervision. Issues in Bank Regulation, 26-37.

SEC. (2008, March). Sample Letter Sent to Public Companies on MD\&A Disclosure Regarding the Application of SFAS 157. Retrieved from http://www.sec.gov/divisions/corpfin/guidance/fairvalueltr0308.htm

Simonson, D. G., \& Hempel, G. H. (1993). Banking Lessons from the Past: The 1938 Regulatory Agreement Interpreted. Journal of Financial Services Research, 249-267. http://dx.doi.org/10.1007/BF01047013

Taub, S. (2007, November 7). FAS 157 Could Cause Huge Write-offs. Retrieved from http://www.cfo.com/article.cfm/10097878 
The Hunt Commission Report. (1971). Report of the President's Commision on Financial Structure and Regulation.

U.S. Congress. (1974). Financial System Reform: Key to a Stable, Growing Economy. Staff Report, 93rd Congress, 2nd Session.

Viner, J. (1939). Recent Legislation and the Banking Situation (pp. 109-110). American Economic Association.

White, L. J. (1991). The S\&L Debacle: Public Policy Lessons for Bank and Thrift Regulation. New York: Oxford University Press.

WSJ. (2008). Credit Storm Back With a Vengeance. Wall Street Journal, 6(7), C.1.

WSJ Heard on the Street. (2008, March 14). SEC Aims to Let Firms Explain Crunch Thorns; Market Prices Still Apply But Plan Offers Leeway; Risk of Too-Rosy Views. Wall Street Journal [New York, N.Y], C.1.

\section{Notes}

Note 1. For further discussion see (Barth, Brumbaugh, \& Litan, 1990) and (Merton, 1977)

Note 2. Estimated dollar costs can be found in Congressional Budget Office (1991). For broader costs of disguising capital impairment in the savings and loans industry see White (1991, pp. 82-90, 223-230).

Note 3. The previous largest bankruptcy was that of WorldCom Inc. in July 2002, which had $\$ 104$ billion of assets. (Mamudi, 2008)

\section{Copyrights}

Copyright for this article is retained by the author(s), with first publication rights granted to the journal.

This is an open-access article distributed under the terms and conditions of the Creative Commons Attribution license (http://creativecommons.org/licenses/by/3.0/). 